\title{
Students' Views on the Use of Critical Thinking-Based Pedagogical Approach for Vocabulary Instruction
}

\author{
Tariq Elyas ${ }^{1} \&$ Budor S. Al-Zahrani ${ }^{2}$ \\ ${ }^{1}$ Department of European Languages \& Literature, Faculty of Arts \& Humanities, King Abdulaziz University, \\ Jeddah, Saudi Arabia \\ ${ }^{2}$ English Language Centre, University of Jeddah, Jeddah, Saudi Arabia \\ Correspondence: Tariq Elyas, Department of European Languages \& Literature, Faculty of Arts \& Humanities, \\ King Abdulaziz University, Jeddah, Saudi Arabia
}

Received: June 18, 2019 Accepted: July 10, 2019 Online Published: August 9, 2019

doi:10.5539/hes.v9n3p116 URL: https://doi.org/10.5539/hes.v9n3p116

\begin{abstract}
This research aimed to explore students' views towards the use of a critical thinking pedagogical model for vocabulary instruction. From this end, a questionnaire was utilized to collect both quantitative and qualitative data to investigate the students' opinions about such an educational experience. Data analysis revealed that the meaningful and purposeful critical thinking vocabulary tasks triggered learners' motivation while engaging their higher cognitive abilities in solving the tasks and enabling them to reflect on their topics based on their personal and life experiences. This challenging process led learners to have more opportunities for practicing 'elaborative rehearsal', and as a result, to process the targeted vocabulary deeper. This created a stronger association with the taught vocabulary, which ultimately enabled them to be encoded in the learners' long-term memory. Based on these findings, the authors recommend that teachers, teacher educators, and curriculum designers should draw upon the findings of these studies and consider the advisability of embedding critical thinking-based teaching methods across all strata of the EFL teaching system: policy documents, curricula, teacher training courses and the language classrooms.
\end{abstract}

Keywords: critical thinking, English as a foreign language, memory, vocabulary instruction, retention

\section{Introduction}

When the English language is currently used as a global language by people from various linguistic and cultural backgrounds, the primary purpose of language learning is to build the L2 learners' communicative competence so that they become capable of communicating in the target language-English (Richards \& Rogers, 2001). According to Gass and Selinker (2008), "lexicon may be the most important language component for learners [that] derives language production" (pp. 449-450). Elyas \& Shah (2018) claims that "research has shown that interactive activities which trigger peer engagement in classrooms can increase learners' knowledge of target vocabulary" (p.1). However, when observing the local contexts, English as Foreign Language (EFL) Saudi learners may be considered not effective communicators when using the target language. Similar to learners in many other contexts, Saudi learners face many problems in their quest for language acquisition (Alnofaie, 2013; Al-Nasser, 2015; Al Zahrani \& Elyas, 2017; Elyas \& Al Zahrani, 2019). One such problem is the learners' lack of an adequate set of English vocabulary, which may impede their willingness to communicate. According to Al-Masrai and Milton (2012), Saudi university students' level is not up to the level associated with fluency in EFL international standards because of their vocabulary size. Also, Saleh (2015) claims that Saudi learners of English at the preparatory year at one of the most prominent universities in Saudi Arabia reported that their main reason for performing poorly in the speaking skill is the lack of vocabulary. In addition, when it comes to class activists, Elyas and Picard (2013) claim that the Saudi education system does support critical thinking and creativity as one of the classrooms' activities. We, therefore, see the importance of vocabulary acquisition in English learning. For example, Richards and Rennandya (2002) stressed the relation of vocabulary and fluency by stating that:

Without an extensive vocabulary. ... learners often achieve less than their potential and may be discouraged from making use of language learning opportunities around them such as listening to the radio, listening to native speakers, using the language in different contexts, reading, watching television. (p. 255) 
Even though translation of newly learned English vocabulary may appear to be a useful strategy, is not necessarily recognized as the best method for learning new words. When students adopt this method as the only means for obtaining the meanings of words, they deprive themselves from learning other related information as, synonyms, antonyms and usages.

The current study examines the attitudes of Saudi learners of English towards the use of the critical thinking (CT) pedagogical model for vocabulary instruction. By exploring the participants' views in detail, this research provides a broader understanding of different aspects of a CT based pedagogical approach for vocabulary instruction from the view of the students.

\section{Literature Review}

\subsection{Definitions on Critical Thinking}

It is not easy to find a definition of (CT) on which most researchers can agree (Lai, 2011) and experts and researchers in the fields of philosophy, cognitive psychology and in education have been proposed many different definitions. This stems from the divergent interests concerning CT across those academic fields. For instance, while the focus in the domain of philosophy is on the abilities and the characteristics of a critical thinker, in cognitive psychology, on the other hand, the focus lies on a critical thinker's behaviour and actions. One of the earliest definitions of CT that was proposed by William Sumner in 1906:

[Critical thinking is] . . the examination and test of propositions of any kind which are offered for acceptance, in order to find out whether they correspond to reality or not. The critical faculty is a product of education and training. It is a mental habit and power. (para. 1)

Angelo (1995) stated that "most formal definitions characterize CT as the intentional application of rational, higher-order thinking skills, such as analysis, synthesis, problem recognition and problem solving, inference and evaluation" (p. 6). In line with Angelo's description of CT, other scholars have stated that higher-order thinking (analysis, synthesis, and evaluation) represents CT (Ennis, 1997; Shirkhani \& Fahim, 2011; Kennedy, Fisher, \& Ennis, 1991; Behdani \& Rashtchi, 2017). Similarly, Facione (1990) also considered higher order thinking skills as characteristics of CT. Anderson et al. (2001) state that "to think critically about an issue probably involves some conceptual knowledge to analyze the issue, and then one can evaluate different perspectives in terms of the criteria and perhaps create a novel yet defensible perspective on the issue" (Brodin, 2007, p. 16).

\subsection{Critical Thinking in Education}

CT is a skill that is subject to improvement. The teachability of CT has been demonstrated (Lai, 2011). In the 1970s, a Critical Thinking Movement was declared to plead for CT empowerment in education (Song, 2016). More than three decades ago, in the Tbilisi Declaration, it was expressed that the ultimate goal of education is to develop CT (Djiwandono, 2013). Cameron (2011) also stated that CT should be taken into consideration when teaching. Similarly, many scholars stated that CT should be the focus of instruction and should be regarded as fundamental to education (Paul \& Binker, 1993; Song, 2016). Others asserted that teaching students to think critically should be among the significant goals of higher education (Angel, 1995; Elder \& Paul, 2010; Cummings, 2015). This recognition of the importance of CT in education is what led Michael Scriven, who served as the president of the American Education Association at that time, to declare in 1997 that CT is an 'academic competency' similar to reading or writing (Fisher, 2001). In 2011, the Association of American Colleges and Universities (AAC\&U) conducted a survey, in which 95\% of the member institutions placed CT as the learning goal for all students (Lennon, 2014). Until the 1990s, critical thinking was only considered important in L1 speaking contexts (Sharifi-Nejad et. al, 2016). Boroushaki \& Ng (2016) claim that "there is a significant relationship between critical thinking and vocabulary learning strategy use (p.15).

Moreover, teachers, education experts, and business leaders have dedicated much effort to arrive at a description of the skills and knowledge students must obtain in order to achieve success and survive in the 21st century. As a result, the Framework for 21 st Century Learning has been created and has been used by many educators and educational institutes in many parts of the world (P21 Partnership for 21st Century Learning, 2009). One of the most targeted learning skills is CT skill or fluency. According to this framework, CT is one of the four essential skills or competencies in this century in addition to communication, collaboration, and creativity, which are known as the 4 Cs. The framework's components are illustrated in Figure 1. 


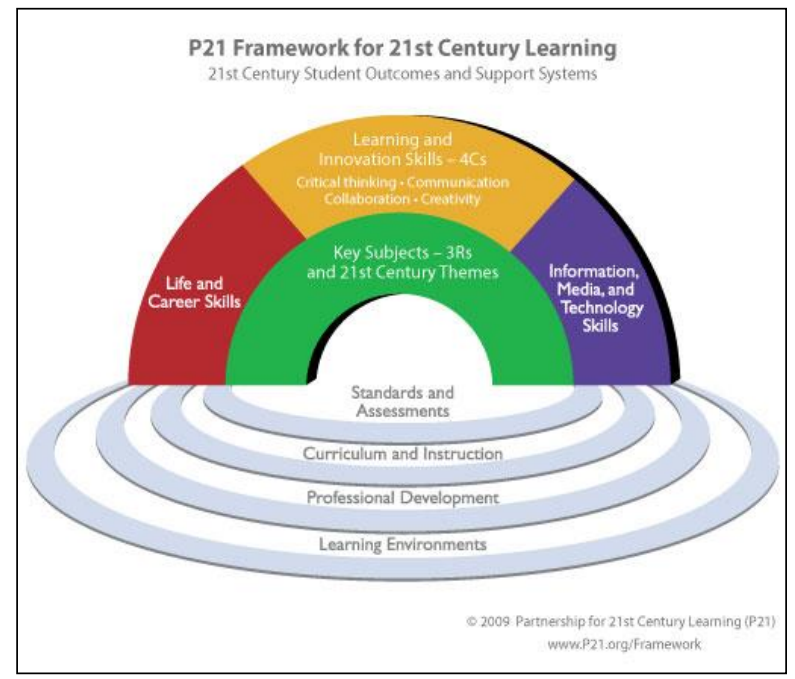

Figure 1. The Framework for $21^{\text {st }}$ Century Learning Components

(Adopted from www.p21.org.)

In practice, however, an adequate pedagogy for CT competency is lacking. Lyman (2014) stated that what is missing from education is $\mathrm{CT}$ and that little attention is paid to its instruction in schools.

$\mathrm{CT}$ in the field of education has been an intriguing area for discussion among researchers and practitioners for many reasons. One area of discussion is whether CT is general or domain specific. In other words, does teaching CT in scientific fields such as in math, for instance, the same as teaching it in other subject areas, such as language teaching or philosophy, for instance? One could argue that, logically, to think critically about $x$ (referring to any topic or issue) relies tremendously on the nature of that $x$ (McPeck, 1981). Despite researchers' different points of view concerning the generalizability or specificity of CT skills or abilities, claiming that CT includes general elements as well as domain specific ones is a view endorsed by many (Ennis, 1989; Facious, 1990, 2000; Paul, 1992; Lai, 2011). This paper, therefore, investigates Saudi EFL students' attitudes towards the use of a CT-based approach in EFL vocabulary instruction.

\section{Methodology}

\subsection{Research Design}

This study used an attitudinal questionnaire to explore students' views on a CT model of vocabulary instruction (see Appendix A). This questionnaire collects both quantitative as well as qualitative data, as it includes closed-ended items and open-ended questions. The first part of the questionnaire requests participants' demographic information. The second part contains five-point Likert-scale questions with eighteen statements. These statements inquire about the extent of the participants' agreement to the following seven themes:

1. Vocabulary retention (5 items)

2. Rehearsal (3 items)

3. Motivation (one item)

4. Student-centered learning (4 items)

5. Problem-solving (one item)

6. Reflection (2 items)

7. Empowerment (2 items)

The last part contains two items requiring open-ended responses. Creswell (2014) describes open-ended questions as "ideal" for exploring possibilities, and adds that such questions permit participants to form responses derived from their cultural and social experiences, as opposed to those of the researcher. A translation in the participants' first language was provided in the same questionnaire to improve comprehension (see Appendix B \& C).

The questionnaire was first examined and revised by two experienced researchers with doctoral degrees in the field of foreign language teaching. It was then piloted with fifteen students who were not from the study's participants. Participants' responses were coded and given numeric values to measure the reliability of the 
questionnaire. The questionnaire was found to be reliable with a Cronbach's Alpha value (.846).

\subsubsection{The Questionnaire's Validity and Reliability}

Statistical analysis was applied to ensure the validity and reliability of the questionnaire as a new research tool. A validity test of inter-item correlations was applied. Pearson's correlation coefficients were calculated for each item with the sum of all items belonging to one single theme. All the themes (or factors) have statistically highly significant correlation $(\mathrm{p}<0.005)$. Moreover, all the themes (factors) of the scale correlated statistically and significantly to the total sum of the scale $(\mathrm{p}<0.005)$. This indicates that the scale is valid and has internal consistency.

To assess the reliability of the questionnaire, Alpha coefficient was calculated for the set of items as a group and the sets for the total scale. Most items showed to be acceptable to good consistency $(0.7,0.8)$, and the total scale showed high value for consistency with Alpha coefficient 0.93. Therefore, the scale has internal consistency and is reliable as a measuring tool.

\subsubsection{Analysis of the Quantitative Section of the Questionnaire}

The second section reports quantitative data (the first section was for demographic information only) and it includes multi-item statements that were used to measure student's responses. A five-point Likert scale was used to collect data from the students. Positively-keyed items were phrased so that an agreement with an item represents a relatively high level of the attribute being measured which is rated on 5-points (Strongly Disagree=1, Disagree $=2$, Neutral $=3$, Agree $=4$, Strongly Agree $=5$ ).

\subsection{Research Context}

The study was conducted in a foundation year English language program at a university in Saudi Arabia. The program provides first-year undergraduate students with a one-year, preparatory, intensive course in English language. It is one of the largest English language programs in Saudi Arabia. It has a quarter system and four levels. The last level brings the students to an intermediate proficiency level. This is equivalent to level B1+ in the Common European Framework of Reference for Languages (CEFR). Passing this level is a prerequisite for students who aim to continue their university studies.

\subsection{Participants and Sampling}

The participants in this research were 74 Saudi female students of EFL in the preparatory year of the baccalaureate degree program at the university. A convenience sample was chosen for the study. Participants were drawn from four different Level 104 classrooms at an English Language Institute (ELI) at a Saudi university. Their ages ranged from 18 to 25 years old. The selection of the four classrooms was based on instructor willingness to participate in the study and the availability of class time in which to run the study.

\subsection{Data Analysis}

Participants' responses to the questionnaire's Likert-scale questions were coded such that every choice was given a numerical value. To ensure the validity and the reliability of the questionnaire as a new research tool, Pearson's correlation coefficients and Alpha coefficient were calculated using statistical analysis. The means of the items within the groups in the questionnaire and the total scale were calculated, and their frequencies were attained. For the open-ended questions on the questionnaire, the researchers analyzed the data thematically using tables. Similar responses sharing ideas were clustered under a unifying theme (see Appendix B \& C).

\section{Results \& Findings}

In the present study, a questionnaire was utilized to assess the participants' opinions about using a CT-based approach to teach EFL vocabulary (See Appendix A). Thirty-four students completed the questionnaire.

\subsection{The Analysis of the Questionnaire's Total Scale}

The students' responses to the questionnaire reported a strong agreement in average to all the statements and ultimately to the scale in general according to the criteria of the weighted mean levels and values where "strongly agree" levels assumed value equals (4.20-5.00). The mean of the questionnaire's total scale is $\mathrm{M}=4.61$, which is equal to "Strongly Agree". Hence, students' responses are significantly reaching the "Strong Agreement" level as represented in Table 1. 
Table 1. The Means of the Questionnaire's Groups' Items and the Total Scale

\begin{tabular}{llll}
\hline & Descriptive Statistics & \\
\hline Factors (Themes) and Total Scale & Weighted Mean & Std. Deviation & Weighted Mean level \\
\hline Vocabulary Retention & 4.74 & 0.37 & Strongly Agree \\
Student-centered Learning & 4.65 & 0.47 & Strongly Agree \\
Motivation & 4.57 & 0.74 & Strongly Agree \\
Empowerment & 4.54 & 0.60 & Strongly Agree \\
Problem solving & 4.54 & 0.66 & Strongly Agree \\
Reflection & 4.54 & 0.52 & Strongly Agree \\
Rehearsal & 4.47 & 0.58 & Strongly Agree \\
Total Scale & 4.61 & 0.42 & Strongly Agree \\
\hline
\end{tabular}

In Figure 2, the items are sorted in a descending order (highest to lowest) based on their means and standard deviations measure. Themes which recorded higher means obtained more responses of agreements to its items or statements. When means were found equal, the theme with the smallest variance was positioned first.

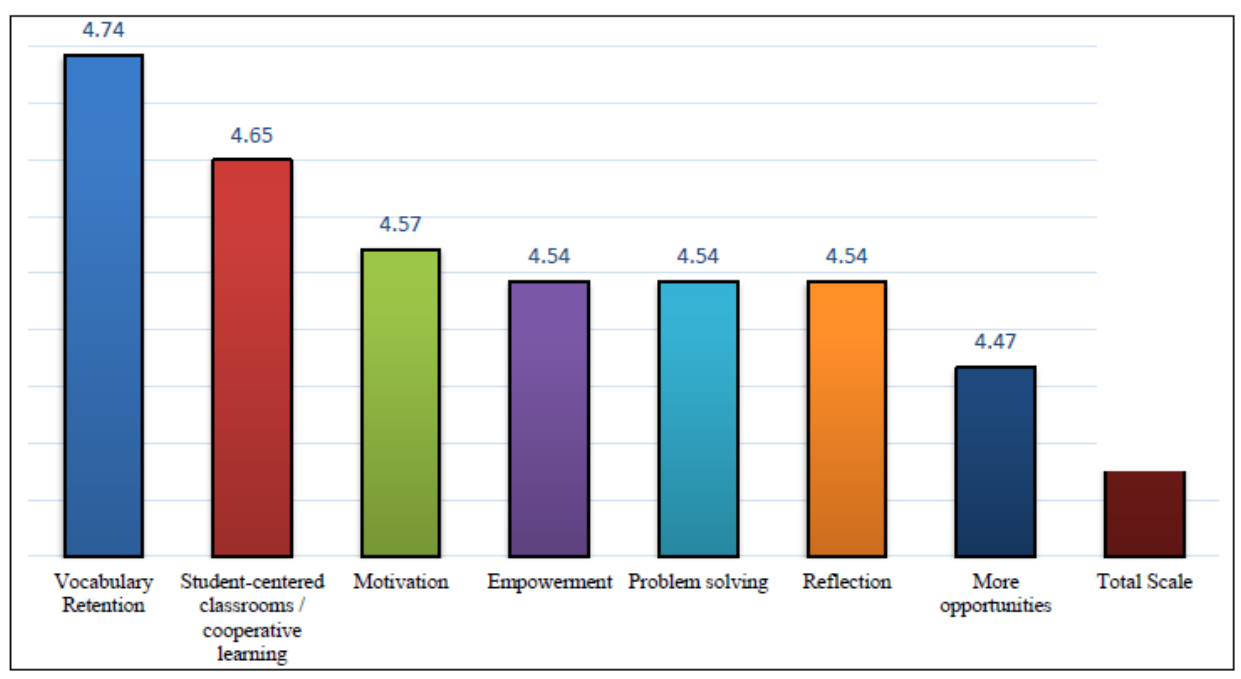

Figure 2. The means of the items in a descending order

\subsubsection{The Analysis of the Questionnaire's Items}

The analysis of the questionnaire themes is presented in forms of frequencies by percentages following their order in the questionnaire.

\subsubsection{Vocabulary Retention}

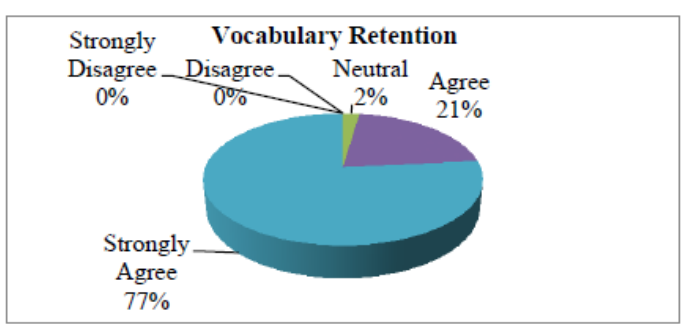

Figure 3. The frequencies of the theme 'vocabulary retention' items

The average of students' responses to the five items labeled under this theme was calculated to reach the frequencies to its theme. Ninety-eight percent of the students agreed with the statements that belong to this theme. Such agreement indicates that all the respondents to the questionnaire except $2 \%$ only believe that the use of CT strategies enhanced their vocabulary retention ability. This means that their ability to retain the meaning 
and the pronunciation of the learned vocabulary after class was improved. Also, their knowledge of the learned vocabulary is more profound compared to the ones learned in other classrooms and, ultimately, studying those words required less time. The means of the responses' of only $2 \%$ of the students were recorded as neutral level. No disagreement was detected in the responses to the statements related to vocabulary retention.

\subsubsection{Rehearsal}

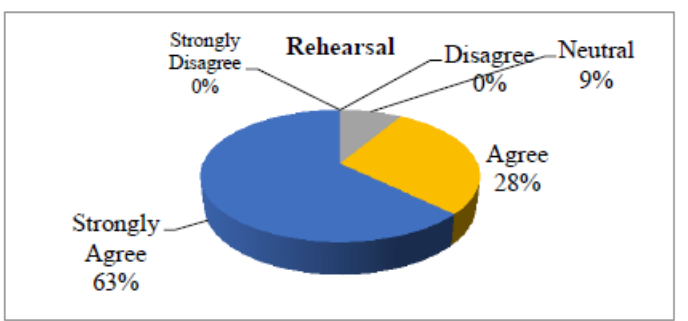

Figure 4. The frequencies of the theme 'rehearsal' items

The average of students' responses to the three items labeled under this theme reflected the agreement of $91 \%$ to its positively composed statements. Sixty-three percent of the students agreed strongly, while $28 \%$ reported agreement. According to students' opinions, they had more opportunities to use the new vocabulary in speaking and writing inside the classroom. Also, the time spent on practicing the new vocabulary, in particular, and their language, in general, inside of the classroom was increased. Around $9 \%$ of the total answers indicated neutral opinions towards these statements.

\subsubsection{Motivation}

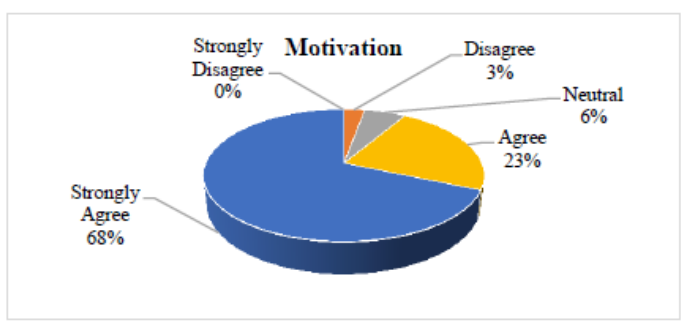

Figure 5. The frequencies of the theme 'motivation' item

Ninety-one percent of the students agreed to the statement that states that their level of motivation increased because of infusing CT. Sixty-eight percent of students agreed with the statement while $6 \%$ preferred to remain neutral to this statement, with only $3 \%$ of the students' responses indicating disagreement with it.

\subsubsection{Student-centered Learning}

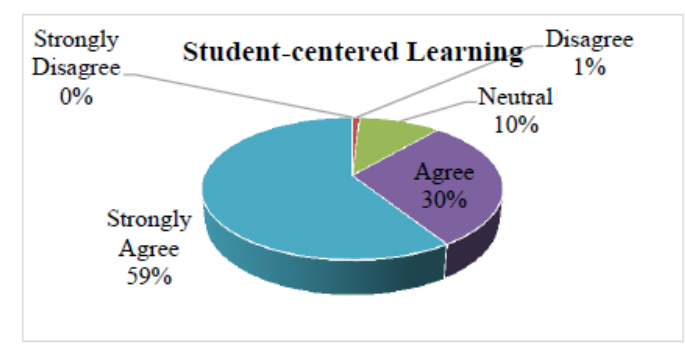

Figure 6. The frequencies of the theme 'student-centered learning' items

The responses to the four statements labeled under this theme recorded around $89 \%$ of agreement to its content. Based on the students' opinions, the majority believed that with the implementation of CT into their EFL classroom, they had more opportunities to cooperate with their colleagues fruitfully. They also enjoyed participating in discussions and dialogues among themselves or with their teacher. As a result, they believed that they had played an active role in these classrooms. 


\subsubsection{Problem Solving}

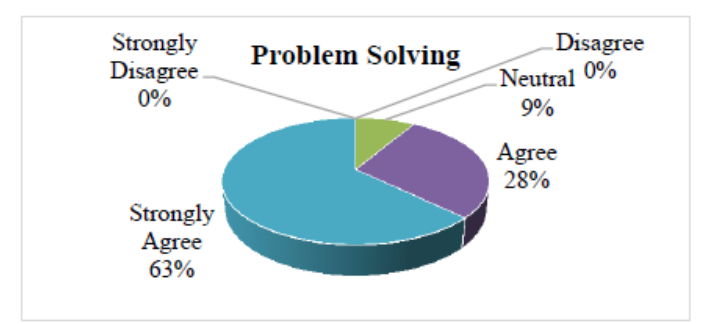

Figure 7. The frequencies of the theme 'problem solving' items

A vast majority of the students (91\%) believed that participating in problem-solving activities was an enjoyable experience. Only $9 \%$ of the students remained neutral towards this statement, while no student reported disagreement.

\subsubsection{Reflection}

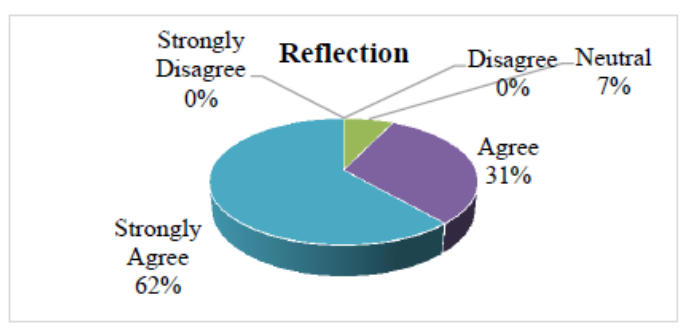

Figure 8. The frequencies of the theme 'reflection' items

Most of the respondents (93\%) reported their agreement to the two statements belonging to reflection. This implies that they think that $\mathrm{CT}$ activities required them to think deeply about themselves and the world around them. Moreover, this indicates that they found themselves capable of connecting these activities to their personal experiences and lives in general outside of the classroom. The remaining respondents (7\%) reported no particular view and stayed neutral.

\subsubsection{Empowerment}

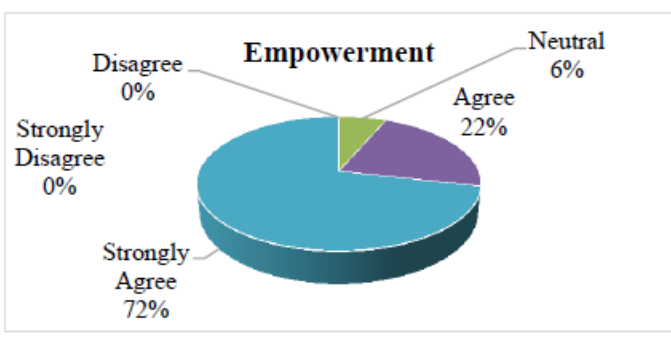

Figure 9. The frequencies of the theme 'empowerment' items

According to an overwhelming majority of the students, the infusion of CT in EFL classrooms empowered them. About $94 \%$ of the respondents indicated that participating in CT activities gave them the confidence to express and justify their opinions. Also, they felt that they were able to make decisions and predictions and to review them. The remaining $6 \%$ of the students remained neutral towards the two statements.

\subsubsection{The Analysis of the Questionnaire's Qualitative Items}

\subsubsection{Influence of $\mathrm{CT}$ on their vocabulary learning}

The analysis of the students' responses to the questionnaire in both the quantitative and the qualitative sections revealed that all the respondents held positive attitudes towards CT implementation in EFL classrooms. The estimation of the average of students' answers in the quantitative section of the questionnaire showed that all the 
statements received strong agreement confirming the benefits of CT. Also, all the respondents' answers to the qualitative questions of the questionnaire about the influence of CT on their vocabulary learning and about their description of this experience indicated that they hold very positive opinions about CT. One student wrote the following describing her experience:

It was an interesting and exciting experience. I hope it could be applied in language curricula and teaching. This method works very well in teaching English language. In some schools, English is handled as a school subject. However, it should be considered more than that: a language. This is because of the way of teaching vocabulary and grammar. I really liked this method and I think it has been extremely useful for students.

This positive attitude towards CT implementation inside EFL classrooms was also found in other studies, such as, in Tahriri (2014) where it was found that more than two-thirds of the participants were interested in using CT skills in the classroom.

\subsubsection{Vocabulary Retention}

First of all, students' responses to the quantitative items showed that they believe that CT did enhance their ability of vocabulary retention. This self-observed improvement included their ability to retain the meaning and the pronunciation of the learnt vocabulary after class. It also includes obtaining more profound knowledge of the learned vocabulary compared to the ones acquired in other classrooms and, ultimately, this led to spending less time in studying those words. Furthermore, vocabulary retention was the most mentioned area of improvement by the implementation of $\mathrm{CT}$ in the open-ended questions in the qualitative section of the questionnaire. The students' responses revealed that they had noticed general improvement, particularly, on the easiness and the speed by which they can retain and remember the learned vocabulary. One student described the effect of CT by writing that "I tend not to forget the words as opposed to other classes". Another student compared CT approach to other conventional methods by writing that: "It is not just the usual way of memorizing vocabulary and then forgetting them later". A third student took a similar stance in that comparison by stating that CT strategies "helped me to better remember and understand vocabulary in comparison with the ordinary method of studying them".

\subsubsection{Studying for Exams}

Another evidence of the enhancement of the students' ability of vocabulary retention was in the second most recurrent area of influence in students' answers in the qualitative part of the questionnaire, which is the influence on their exam preparation. They claimed that the implementation of the CT-based approach made their studying of the targeted vocabulary for exams more comfortable and required less time to revise compared to other words taught using other conventional methods. This indicates that a stronger connection was established between the learned words and the students' memory, leading to more comfortable and faster studying and recall.

\subsubsection{Vocabulary Learning and Usage}

Other students also mentioned other benefits for implementing CT, as indicated in one of the quotes from a student who stated that CT strategies "were excellent in clarifying meanings of words and in comparing them with each other". Others went on to say that they became more capable of using the words effectively in sentences. For instance, one student wrote that CT strategies "made putting [the words] in sentences a lot easier". Similarly, another student stated that "using those strategies was effective... as in when and how to use it in expressions and in speech". These results are consistent with Elder and Paul's (2010) claim that promoting CT in teaching enables the learner to understand the subject matter deeply and explain, apply, and transfer knowledge to real life.

\subsubsection{Empowerment}

Other students noticed that adopting the CT-based approach created a sense of empowerment for them. According to an overwhelming majority of the students (94\%), participating in CT activities gave them confidence to express and justify their opinions. A student stated that discussions held inside CT classrooms "could make the student more confident in talking". Besides, they felt that they were able to make decisions and predictions and to review them. These results are consistent with the findings of Fairley's (2009) study that using debates as part of CT practices led to female empowerment in mixed genders' classroom participation. It is also consistent with what Shin and Crookes (2005) noted which is that lessons emphasizing CT on relevant topical issues enable students to make decisions whether inside or outside classrooms (as cited in DeWaelsche, 2015, p.140). 


\subsubsection{Problem Solving}

The majority of the respondents considered that participating in problem solving activities was an enjoyable experience. This positive attitude is due to the fact that incorporating CT in FLT makes language meaningful (Shirkhani \& Fahim, 2011) since they have another goal to accomplish in addition to the regular linguistic requirements of regular tasks, such as a problem to solve or an argument or a debate to resolve. This adoption of problem solving tasks in $\mathrm{CT}$ is also a promoting factor for the effectiveness of $\mathrm{CT}$ on vocabulary retention. As previously mentioned in the experimental study of Mortaji and Pour (2014), the teaching of new words in the form of problem solving had a positive effect on the immediate and delayed retention.

\subsubsection{Student-Centred Learning}

In addition to the previously discussed points, the majority of respondents believed that the implementation of a CT-based approach in their EFL classroom encouraged them to play active roles in the classrooms in which they have cooperated fruitfully with their colleagues. They also reported that they have enjoyed participating in discussions and dialogues among themselves or with their teacher. Collaborative dialogue, which is only one of the CT strategies, has been found to have a positive influence on vocabulary acquisition and retention (Ahmadian, Amerian, \& Tajabadi, 2014). Another benefit of creating such student-centred classrooms is that they raise the students' level of intrinsic motivation in EFL (Griffiths, 2008; as cited in Alharbi, 2015).

\subsubsection{Motivation}

CT, in general, has been associated with motivation with claims that challenging tasks which demand higher-order thinking skills promote students' motivation (Turner, 1995; as cited in Lai, 2011) and that is what leads to proficient EFL learners (Rafi, 2011). This association between CT and motivation was also found in the practical study of Afshar, Rahimi, A. and Rahimi, M. (2014), where a clear correlation between CT and motivation was drawn. This increase in students' level of motivation as a result of CT implementation has been acknowledged by the students in the current study. A vast majority of the students (91\%) agreed strongly to the statement that states that their level of motivation increased as a result of CT implementation. In addition, this point constituted one of the most recurrent themes in the students' answers to the open-ended questions. When students were asked to describe their attitude towards this research educational experience, one student stated that "it was a highly enjoyable experience. The class was no longer boring; it was not just reading and writing any more". Other students described their experiences as "enjoyable and beneficial at the same time", and that "classes were much more enjoyable than usual". This causal relationship between promoting CT in teaching and increasing the learner's level of motivation is clearly indicated in the work of Elder and Paul (2010).

\subsubsection{Reasons for the Efficacy of a CT-based Approach}

Motivation is only one significant factor that contributed to CT effectiveness in vocabulary retention. Another important factor and an aspect of CT that can profoundly impact the retention of vocabulary is reflection. The researchers intended to include topics that are based on student interests, relevant personal and life experiences and that include social issues as well as unique aspects of Saudi culture; all of which to incorporate this significant aspect of CT, namely, reflection. Creating an emotional and mental connection with vocabulary tasks engages the students and enables them to practice reflection. "An orienting task requiring semantic or affective judgments led to better memory performance than tasks involving structural or syntactic judgments" (Golonka et al., 2012, P. 276). In the current study, the vast majority of the students consented strongly to the items that state that CT activities required them to think deeply about themselves and the world around them. This indicates that they found themselves capable of connecting these activities to their personal experiences and lives in general outside of the classroom. One student reported that one of the benefits of CT implementation is that "it helped... [her] in connecting... [the words] with... [her] personal life." This deepens the link and the association created with the new vocabulary and increases its chances of being better recalled and retained.

\section{Discussion}

\subsection{The Proposed Model of the Role of CT in EFL Vocabulary Retention}

This CT-based approach to EFL vocabulary instruction views vocabulary learning as an educational experience that is not linear or direct, but instead a process of trials and errors that is driven by the students' motivation and executed by applying higher-cognitive skills and consolidated by their reflection which again requires intellectual skills. A visualization of this approach is demonstrated in Figure 10 which is close to Dwyer et al. (2014) Integrative Framework of Critical Thinking of the $21^{\text {st }}$ Century. However, one main difference between the framework of Dwyer et al. and the proposed model by this study is that while both models view the concept of reflection as a component of $\mathrm{CT}$, Dwyer et al.'s framework uses the term 'reflective judgment' indicating the 
practice of defending judgment and reasoning. Their framework perceives reflection as a skill that is more associated with CT dispositions.

However, in the proposed model by this study, reflection serves a more of a sentimental or an emotional role for promoting retention. Students have to reflect on the topics of the vocabulary tasks by engaging their personal and social life experiences, thus, creating a connection between the learned vocabulary and their memory. Also, reflection is a later stage in a process that is induced initially by motivation. The meaningful learning available in vocabulary CT tasks, on the other hand, triggers motivation, where learners have other goals to accomplish beside the regular linguistic tasks. Motivation is not only the initial step in this educational process, but it also has another purpose, which is to increase the learners' attention that is a requisite in the Multi-Store Model for input to become intake.

In the proposed model, the CT-based approach for vocabulary retention is viewed as a multi-directional process of engaging learners' higher cognitive abilities to solve the vocabulary tasks and to reflect on their topics. In this circular process, 'elaborative rehearsal' that increases the learners' effort and time of practice leads to deeper processing of vocabulary and enables them to be, ultimately, encoded in the learners' long-term memory. Thus, easing the manner and speeding the time for retrieval and remembrance as reported by the students themselves. As one student states describing the effect of CT approach on her vocabulary retention, "I have learnt English vocabulary by heart; I can easily recall any item."

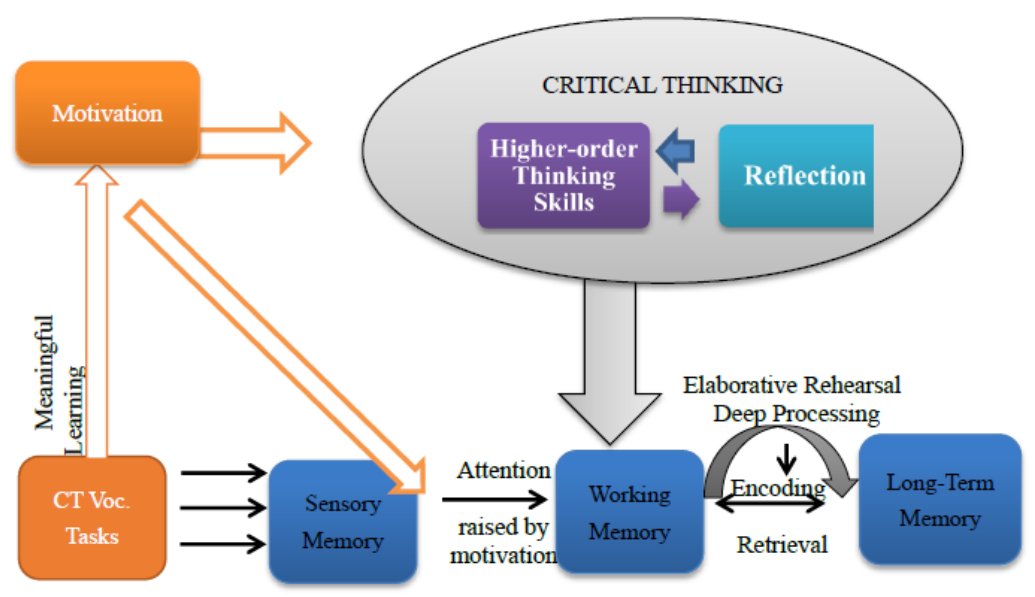

Figure 10. A model of critical thinking role in EFL vocabulary retention

\section{Conclusion}

The current research examined the students' attitudes towards the use of a CT pedagogical model. A questionnaire was utilized to collect both quantitative and qualitative data in order to investigate the students' opinions about such an educational experience. Data analysis revealed that the meaningful and purposeful CT vocabulary tasks triggered learners' motivation while engaging their higher cognitive abilities in solving the tasks and enabling them to reflect on their topics based on their personal and life experiences. This challenging process led learners to have more opportunities for practicing 'elaborative rehearsal', and as a result, to process the targeted vocabulary deeper. This created a stronger association with the taught vocabulary which ultimately enabled them to be encoded in the learners' long-term memory. For practical steps to be taken to implement CT based approaches in classrooms, practitioners need to have a body of literature to draw on. With the current study having been conducted in the Saudi context, it is recommended that more studies be conducted in many different contexts to further add to the body of literature on this field. Further studies should also focus on the impact of CT based pedagogical approaches on students of different proficiency levels. The participants of the current study were at the B1+ level of the CEFR. Studies conducted with students of lower proficiency levels could shed light on whether the level of linguistic proficiency is in any way a significant variable in allowing students to engage in CT based activities.

\section{References}

Afshar, H., Rahimi, A., \& Rahimi, M. (2014). Instrumental motivation, critical thinking, autonomy and academic achievement of Iranian EFL learners. Issues of Educational Research, 24(3), 281-299. 
Ahmadian, M., Amerian, M., \& Tajabadi, A. (2014). The effect of collaborative dialogue on EFL learner's vocabulary acquisition and retention. International Journal of Applied Linguistics \& English Literature, 3(4), 38-45. https://doi.org/10.7575/aiac.ijalel.v.3n.4p.38

Alharbi, H. (2015). Improving students' English speaking proficiency in Saudi public schools. International Journal of Instruction, 8(1), 105-117. https://doi.org/10.12973/iji.2015.818a

Al-Masrai, A., \& Milton, J. (2012). The Vocabulary Knowledge of University Students in Saudi Arabia. TESOL Arabia Perspectives, 19 (3).

Al-Nasser, A. (2015). Problems of English Language Acquisition in Saudi Arabia : An Exploratory-cum-remedial Study, 5(8), 1612-1619. https://doi.org/10.17507/tpls.0508.10

Alnofaie, H. (2013). The implementation of critical thinking as EFL pedagogy: Challenges and opportunities (Doctoral dissertation, Newcastle University). Retrieved from http://hdl.handle.net/10443/2326

Al Zahrani, B. S., \& Elyas, T. (2017). The Implementation of Critical Thinking in a Saudi EFL Context: Challenges and Opportunities. IJELTAL (Indonesian Journal of English Language Teaching and Applied Linguistics), 1(2), 133-141. https://doi.org/10.21093/ijeltal.v1i2.21

Angelo, T. (1995). Beginning the dialogue: Thoughts on promoting critical thinking: Classroom assessment for critical thinking. Teaching of Psychology, 22(1), 6-7. https://doi.org/10.1207/s15328023top2201_1

Behdani, S., \& Rashtchi, M. (2017). The relationship between vocabulary recall and critical thinking. Journal of Teaching English Language Studies, 5(3). 52-68.

Boroushaki, N., \& Ng, Lee-L. (2016). Critical thinking ability and vocabulary learning strategy use: The case of EFL learners in an ESL context, Journal of Language and Translation, 6(11), 1-15.

Brodin, E. (2007). Critical Thinking in Scholarship: Meanings, Conditions and Development. (Doctoral dissertation, Lund University). Retrieved from http://portal.research.lu.se/portal/en/publications/critical-thinking-in-scholarship-meanings-conditions-anddevelopment

Cameron, T. (2011). Critical thoughts on critical thinking in Saudi Arabia. Retrieved from https://www.opendemocracy.net/bobby-thomas-cameron/critical-thoughts-on-critical-thinking-in-saudi-arab ia

Cummings, B. (2015). Critical thinking: A developmental education perspective. RTDE, 32(1), 68-72.

DeWaelsche, S. (2015). Critical thinking, questioning and student engagement in Korean university English courses. Linguistics and Education, 33, 131-147. https://doi.org/10.1016/j.linged.2015.10.003

Djiwandono, P. (2013). Critical thinking skills for language students. TEFLIN Journal, 24(1), 32-47. http://dx.doi.org/10.15639/teflinjournal.v24i1/32-47

Dwyer, C., Hogan, M., \& Stewart, I. (2014). An integrated critical thinking framework for the 21st century. Thinking Skills \& Creativity, 12, 43-52. https://doi.org/10.1016/j.tsc.2013.12.004

Elder, L., \& Paul, R. (2010). Critical thinking development: A stage theory. Retrieved from http://www.criticalthinking.org/pages/critical-thinking-development-a-stagetheory/483

Elyas, T., \& Al-Zahrani, B. S. (2019). The impact of critical thinking on learners' EFL vocabulary retention: The Arab context. Indonesian EFL Journal, 5(2), 11-30. https://doi.org/10.25134/ieflj.v5i2.1901

Elyas, T., \& Shah, S. R. (2018). Teaching/Developing Vocabulary through Peer Engagement and Interactive Strategies. The TESOL Encyclopedia of English Language Teaching. 1-7. Wiley-Blackwell Publishing (Editor-in-chief: John I. Liontas). https://doi.org/10.1002/9781118784235.eelt0742

Elyas, T., \& Picard, M. (2013). Critiquing of higher education policy in Saudi Arabia: towards a new neoliberalism. Education, Business and Society: Contemporary Middle Eastern Issues, 6(1), 31-41. https://doi.org/10.1108/17537981311314709

Ennis, R. (1997). Incorporating critical thinking in the curriculum: An introduction to some basic issues. Inquiry: Critical Thinking across the Disciplines, Spring, 16(3), 1-9. https://doi.org/10.5840/inquiryctnews199716312

Facione, P. (1990). Critical thinking: A statement of expert consensus for purposes of educational assessment and instruction executive summary —The Delphi Report. The California Academic Press, 423(c), 1-19. 
Fairley, M. (2009). De-silencing female voices: the use of controversial debate topics in the EFL classroom. In Wachob, P. (Eds.), Power in the EFL Classroom: Critical Pedagogy in the Middle East (1). Newcastle-upon-Tyne, United Kingdom: Cambridge Scholars Publishing, 55-73. Retrieved from http://www.ebrary.com

Fisher, A. (2001). Critical thinking; An introduction. Library, 44(13), 17. http://doi.org/10.2307/2019787

Gass, S., \& Selinker, L. (2008). Second Language Acquisition: An Introductory Course (3rd Edition). New York, NY: Routledge/Taylor Francis. https://doi.org/10.4324/9780203932841

Kennedy, M., Fisher, M., \& Ennis, R. (1991). Critical thinking: Literature review and needed research. In Idol, L. and Jones, B.P. (Eds.), Educational Values and Cognitive Instruction: Implications for Reform. Hillsdale, N.J.: Lawrence Erlbaum.

Lai, E. R. (2011). Critical thinking: A literature review. Pearson Assessment. Retrieved from http://images.pearsonassessments.com/images/tmrs/CriticalThinkingReviewFINAL.pdf

Lennon, N. (2014). How professors infuse critical thinking into college courses. (Doctoral dissertation, Seton Hall University). (Order No. 3645747). Available from ProQuest Dissertations \& Theses Global. (1626405878). Retrieved April, 2016, from http://search.proquest.com/docview/1626405878?accountid=142908

Lyman, S. (2014, December 24). What's missing from education? Critical thinking. [Blog post]. Retrieved from http://www.xconomy.com/seattle/2014/12/24/whats-missing-from-education-criticalthinking/\#

McPeck, J. (1981). Critical Thinking and Education. New York: St. Martin's.

P21 Partnership for 21 st Century Learning (2009). Framework for 21st Century Learning. Retrieved November 22, 2015, from http://www.p21.org/about-us/p21-framework.

Rafi, M. (2011). Promoting critical pedagogy in language education. International Research Journal of Arts and Humanities, 39(39), 63-73. Retrieved from http://search.proquest.com/docview/1354331910?accountid=150994

Richards, J., \& Rogers, T. (2001). Approaches and methods of language teaching (2 ${ }^{\text {nd }}$ ed.). Cambridge: Cambridge University Press. https://doi.org/10.1017/CBO9780511667305

Richards, J., \& Renandya, W. (2002). Methodology in language teaching: An anthology of current practice. New York: Cambridge University Press. https://doi.org/10.1017/CBO9780511667190

Saleh, A. (2015). Improving students' English speaking skill through an Islamic based syllabus: A reflective approach (Master's thesis, King Abdulaziz University).

Sharafi-Nejad, M., Raftari. S., \& Shaik Abdul Malik, Mohamed. (2016). Exploring the effectiveness of critical thinking on vocabulary learning by Malaysian EFL learners, Journal of Studies in Education, 6(2), 24-39. https://doi.org/10.5296/jse.v6i2.9520

Shirkhani, S., \& Fahim, M. (2011). Enhancing critical thinking in foreign language learners. Procedia - Social and Behavioural Sciences, 29, 111-115. http://doi.org/10.1016/j.sbspro.2011.11.214

Song, X. (2016). Critical Thinking and Pedagogical Implications for Higher Education. East Asia, 33(1), 25-40. http://doi.org/10.1007/s12140-015-9250-6

\section{Appendix A}

Section A:

Your name (optional):

Your age: $\square$ Below 18 years $\square$ From 18 to 22 years $\square$ From 23 to 26 years $\square$ Above 26 years

Section B:

Please indicate your level of agreement with the following statements about implementing critical thinking strategies in teaching English language vocabulary by putting $(\sqrt{ })$ under the best answer that reflects your opinion. 


\begin{tabular}{|c|c|c|c|c|c|c|}
\hline No. & The Statements & $\begin{array}{l}\text { Strongly } \\
\text { Agree }\end{array}$ & Agree & Neutral & $\begin{array}{l}\text { Strongly } \\
\text { Disagree }\end{array}$ & Disagree \\
\hline 1 & $\begin{array}{l}\text { My ability to retain the learned vocabulary } \\
\text { after class was improved. }\end{array}$ & $\square$ & $\square$ & $\square$ & $\square$ & $\square$ \\
\hline 2 & $\begin{array}{l}\text { My ability to retain the meaning of the learned } \\
\text { vocabulary after class was improved. }\end{array}$ & $\square$ & $\square$ & $\square$ & $\square$ & $\square$ \\
\hline 3 & $\begin{array}{l}\text { My ability to retain the pronunciation of the } \\
\text { learned vocabulary after class was improved. }\end{array}$ & $\square$ & $\square$ & $\square$ & $\square$ & $\square$ \\
\hline 4 & $\begin{array}{l}\text { Studying those words required less time as } \\
\text { opposed to other words learned in other } \\
\text { lectures. }\end{array}$ & $\square$ & $\square$ & $\square$ & $\square$ & $\square$ \\
\hline 5 & $\begin{array}{l}\text { My knowledge of the learned vocabulary is } \\
\text { deeper compared to the ones learned in } \\
\text { previous classrooms. }\end{array}$ & $\square$ & $\square$ & $\square$ & $\square$ & $\square$ \\
\hline 6 & $\begin{array}{l}\text { I had more opportunities to use the new } \\
\text { vocabulary in speaking and writing inside } \\
\text { classroom. }\end{array}$ & $\square$ & $\square$ & $\square$ & $\square$ & $\square$ \\
\hline 7 & $\begin{array}{l}\text { Time spent on practicing the new vocabulary } \\
\text { inside classroom was increased. }\end{array}$ & $\square$ & $\square$ & $\square$ & $\square$ & $\square$ \\
\hline 8 & $\begin{array}{l}\text { I had more time to practice my language while } \\
\text { doing the activities. }\end{array}$ & $\square$ & $\square$ & $\square$ & $\square$ & $\square$ \\
\hline 9 & The activities raised my level of motivation. & $\square$ & $\square$ & $\square$ & $\square$ & $\square$ \\
\hline 10 & $\begin{array}{l}\text { I had more opportunities to cooperate fruitfully } \\
\text { with my colleagues inside classroom. }\end{array}$ & $\square$ & $\square$ & $\square$ & $\square$ & $\square$ \\
\hline 11 & $\begin{array}{l}\text { I enjoyed participating in discussions and } \\
\text { dialogues with my colleagues. }\end{array}$ & $\square$ & $\square$ & $\square$ & $\square$ & 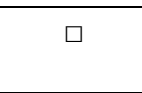 \\
\hline 12 & $\begin{array}{l}\text { I enjoyed participating in discussions and } \\
\text { dialogues with my classroom teacher. }\end{array}$ & $\square$ & $\square$ & $\square$ & $\square$ & $\square$ \\
\hline 13 & I played a more active role in these classes. & $\square$ & $\square$ & $\square$ & $\square$ & $\square$ \\
\hline 14 & $\begin{array}{l}\text { I enjoyed participating in problem solving } \\
\text { activities. }\end{array}$ & $\square$ & $\square$ & $\square$ & $\square$ & $\square$ \\
\hline 15 & $\begin{array}{l}\text { The activities required me to think deeply } \\
\text { about myself and the world around me. }\end{array}$ & $\square$ & $\square$ & $\square$ & $\square$ & $\square$ \\
\hline 16 & $\begin{array}{l}\text { I was able to connect the activities to my } \\
\text { personal experiences and life in general outside } \\
\text { classroom. }\end{array}$ & $\square$ & $\square$ & $\square$ & $\square$ & $\square$ \\
\hline 17 & $\begin{array}{l}\text { I was confident to express my opinions and to } \\
\text { justify them. }\end{array}$ & $\square$ & $\square$ & $\square$ & $\square$ & $\square$ \\
\hline 18 & $\begin{array}{l}\text { I was able to make decisions and predictions } \\
\text { and to review them. }\end{array}$ & & & & & \\
\hline
\end{tabular}

Section C:

1. In your own words, how does implementing critical thinking affect your vocabulary learning?

2. How would you describe your experience?

\section{Appendix B}

The symbol (n.) refers to the total number of the students while (St.) is an abbreviation of the word 'student' to indicate student's assigned code or number in the present study.

The Analysis of Students' Answers to the First Open-ended Question 


\begin{tabular}{|c|c|c|c|c|c|}
\hline No. & Category & D & $\%$ & Students' Comments & St. \\
\hline 1 & $\begin{array}{l}\text { General Positive } \\
\text { Description }\end{array}$ & 6 & $18 \%$ & $\begin{array}{l}\text { "Yes, it has positively influenced me" } \\
\text { "That has a significant influence" } \\
\text { "It was a very useful experience" } \\
\text { "I was significantly influenced by the strategies" } \\
\text { "The strategies were of a positive influence on me" } \\
\text { "These were very good and useful strategies" }\end{array}$ & $\begin{array}{l}5 \\
7 \\
24 \\
26 \\
27 \\
31\end{array}$ \\
\hline 2 & $\begin{array}{l}\text { Vocabulary } \\
\text { Retention }\end{array}$ & 19 & $56 \%$ & & \\
\hline 2.1 & $\begin{array}{l}\text { Vocabulary } \\
\text { Retention } \\
\text { (General } \\
\text { improvement) }\end{array}$ & 10 & $29 \%$ & $\begin{array}{l}\text { "I bave noticed that whenever I attend a class in which } \\
\text { these strategies are inmlemented, I tend not to forget the } \\
\text { vocabularies" } \\
\text { "Words were solid in our memories and we have been } \\
\text { able to recall them in our everyday lives" } \\
\text { "Leanning became easier and vocabulary meanings were } \\
\text { retained" } \\
\text { "Using these strategies allows us to remember the words. } \\
\text { Real exanyles we had in the class helped us retain the } \\
\text { vocabulary" } \\
\text { "In exams, I remembered those words more than others" } \\
\text { "Although my absence was frequent in that level, I still } \\
\text { remember what you used to teach us in the classes that I } \\
\text { have attended with you" } \\
\text { "These meanings became really retained. Even if I could } \\
\text { not pronounce the word, I could easily recognize it" } \\
\text { "They help in retaining the information better" } \\
\text { "Although the classes are over, I still did not forget the } \\
\text { meanings of the words" } \\
\text { "Connecting these vocabulary items to sentences was } \\
\text { very useful because I would never forget them quickly as } \\
\text { usual" }\end{array}$ & $\begin{array}{l}23 \\
27 \\
29 \\
30\end{array}$ \\
\hline 2.2 & $\begin{array}{l}\text { Vocabulary } \\
\text { Retention } \\
\text { (Easines5) }\end{array}$ & 6 & $18 \%$ & $\begin{array}{l}\text { "They made remembering vocabulary... a lot easier" } \\
\text { "This way made it easier for me to ... remember } \\
\text { vocabulary to a great extent" } \\
\text { "It was easier ... to retain information" } \\
\text { "Thanks to using these strategies, I have become able to } \\
\text { easily remember the vocabulary" } \\
\text { "The strategies made it easier for me and for other } \\
\text { student to understand and to retain information more" } \\
\text { "T have learut English vocabulary by beart; I can easily } \\
\text { recall any item" }\end{array}$ & $\begin{array}{l}11 \\
17 \\
24 \\
28 \\
32 \\
34\end{array}$ \\
\hline 2.3 & $\begin{array}{l}\text { Vocabulary } \\
\text { Retention } \\
\text { (Speed) }\end{array}$ & 3 & $9 \%$ & $\begin{array}{l}\text { "Critical thinking strategies can belp in making } \\
\text { associations between information and in retaining it } \\
\text { faster" } \\
\text { "The moment I see the word, I instantly recognize it and } \\
\text { I found that I already comprehend it" } \\
\text { "It was ... faster to retain information" }\end{array}$ & $\begin{array}{l}16 \\
24\end{array}$ \\
\hline 3 & Vocabulary & 9 & $26 \%$ & & \\
\hline
\end{tabular}




\begin{tabular}{|c|c|c|c|c|c|}
\hline & learning & & & & \\
\hline 3.1 & $\begin{array}{l}\text { Vocabulary } \\
\text { learning } \\
\text { (General } \\
\text { improvement) }\end{array}$ & 1 & $3 \%$ & $\begin{array}{l}\text { "They have constantly and massively increased my } \\
\text { knowledge of vocabulary" }\end{array}$ & 6 \\
\hline 3.2 & $\begin{array}{c}\text { Vocabulary } \\
\text { learning (Manner of } \\
\text { learning: easiness) }\end{array}$ & 1 & $3 \%$ & $\begin{array}{l}\text { "I think this strategy is highly beneficial in easily } \\
\text { learning English vocabulary items" }\end{array}$ & 1 \\
\hline 3.3 & $\begin{array}{l}\text { Vocabulary } \\
\text { learning } \\
\text { (Manner of } \\
\text { learning: speed) }\end{array}$ & 2 & $6 \%$ & $\begin{array}{l}\text { "I could quickly learn vocabulary" } \\
\text { "I get a lot of words in a very fast way and after the } \\
\text { lecture I do not have to study them since I have already } \\
\text { learned them well" }\end{array}$ & $\begin{array}{l}7 \\
14\end{array}$ \\
\hline 3.4 & $\begin{array}{l}\text { Vocabulary } \\
\text { learning } \\
\text { (Comprehension of } \\
\text { meaning) }\end{array}$ & 5 & $15 \%$ & $\begin{array}{l}\text { "It was actually a brilliant and clearly effective idea in } \\
\text { getting to learn and understand new vocabulary" } \\
\text { "Those wonderful strategies were excellent in clarifying } \\
\text { meanings of words and in comparing them with each } \\
\text { other" } \\
\text { "It helped me in understanding the meanings of words" } \\
\text { "Using those strategies was effective as I had come to } \\
\text { understand the literal meaning of a word" } \\
\text { "They were useful for understanding meanings of } \\
\text { vocabulary" }\end{array}$ & $\begin{array}{l}11 \\
23 \\
33\end{array}$ \\
\hline 4 & $\begin{array}{l}\text { Vocabulary use in } \\
\text { sentences }\end{array}$ & 7 & $21 \%$ & $\begin{array}{l}\text { "We can use them in sentences" } \\
\text { "They made putting them in sentences a lot easier" } \\
\text { "After being familiar with these strategies, I know how } \\
\text { to use...vocabulary items. This has been easier than ever } \\
\text { before" } \\
\text { "Using those strategies was effective... as in when and } \\
\text { how to use it in expressions and in speech" } \\
\text { "They also made me understand and better use } \\
\text { vocabulary in the sentences" } \\
\text { "I learned also how and where to use vocabulary items in } \\
\text { sentences" } \\
\text { "They were useful for ... using them in sentences" }\end{array}$ & $\begin{array}{l}10 \\
11 \\
22 \\
23 \\
26 \\
28 \\
33\end{array}$ \\
\hline 5 & $\begin{array}{l}\text { Motivation/ } \\
\text { Engagement }\end{array}$ & 7 & $21 \%$ & $\begin{array}{l}\text { "I think this strategy is highly beneficial in ... learning } \\
\text { English vocabulary items with enjoyment" } \\
\text { "It aims at teaching the subject enjoyably" } \\
\text { "I think it was a very smart method which I enjoyed" } \\
\text { "That was also enjoyable" } \\
\text { "I enjoyed the activities and strategies" } \\
\text { "It felt enjoyable to study English language" } \\
\text { "Learning vocabulary became an enjoyable experience } \\
\text { for me" }\end{array}$ & $\begin{array}{l}1 \\
3 \\
8 \\
15 \\
19 \\
24 \\
30\end{array}$ \\
\hline 6 & $\begin{array}{l}\text { Student-centered } \\
\text { Learning }\end{array}$ & 3 & $9 \%$ & $\begin{array}{l}\text { "I think this strategy is highly beneficial in ... learning } \\
\text { English vocabulary items ... in participation with all } \\
\text { students" } \\
\text { "Communication with the teacher and girls was an } \\
\text { enjoyable experience" }\end{array}$ & 1 \\
\hline
\end{tabular}




\begin{tabular}{|c|c|c|c|c|c|}
\hline & & & & $\begin{array}{l}\text { "For a student, changing the method of teaching could } \\
\text { significantly influence his/her leaning and make her } \\
\text { more interactive. The influence could be greater if the } \\
\text { change is for a better method and if the teacher is } \\
\text { capable of holding personal and social discussions with } \\
\text { students" }\end{array}$ & 25 \\
\hline 7 & Studying for exams & 18 & $53 \%$ & & \\
\hline 7.1 & $\begin{array}{l}\text { Studying for exams } \\
\text { (Usefulness) }\end{array}$ & 3 & $9 \%$ & $\begin{array}{l}\text { "That was extremely useful to me in my exams" } \\
\text { "I feel I really benefitted from the activities because } \\
\text { they really were useful in many things, especially in } \\
\text { exams" } \\
\text { "The strategies influenced the way I study and memorize } \\
\text { vocabulary. They helped me a lot before the exam" }\end{array}$ & $\begin{array}{l}15 \\
16\end{array}$ \\
\hline 7.2 & $\begin{array}{l}\text { Studying for exams } \\
\text { (Easiness) }\end{array}$ & 7 & $21 \%$ & $\begin{array}{l}\text { "The strategies made it easier for me to study and easier } \\
\text { to remember vocabulary" } \\
\text { "This way made it easier for me to study" } \\
\text { "That was an easier method when it came to studying } \\
\text { and memorizing" } \\
\text { "When I learned that those vocabulary items you taught } \\
\text { us are from the book, I then realized that you made it } \\
\text { really easier for me to study them" } \\
\text { "They helped me a lot before the exam It was no more } \\
\text { difficult to study the vocabulary" } \\
\text { "After being familiar with these strategies, I know how } \\
\text { to ...revise vocabulary items. This has been easier than } \\
\text { ever before" } \\
\text { "I believe the strategies were very useful and helpful in } \\
\text { studying and memorizing vocabulary in an easier } \\
\text { manner" }\end{array}$ & $\begin{array}{l}21 \\
22\end{array}$ \\
\hline 7.3 & $\begin{array}{l}\text { Studying for exams } \\
\text { (Time spent) }\end{array}$ & 3 & $9 \%$ & $\begin{array}{l}\text { "While studying, it took no more than } 30 \text { minutes for all } \\
\text { the words we had to study" } \\
\text { "They made me study and memorize vocabularies in a } \\
\text { quicker and faster manner" } \\
\text { "During studying these vocabulary items, I did not spend } \\
\text { a lot of time to memorize them" }\end{array}$ & $\begin{array}{l}23 \\
26 \\
34\end{array}$ \\
\hline$\overline{8}$ & $\begin{array}{l}\text { Preference over } \\
\text { other vocabulary } \\
\text { instruction methods }\end{array}$ & 5 & $15 \%$ & $\begin{array}{l}\text { "We need to have this same experience with all our } \\
\text { teachers since it aims at teaching the subject enjoyably } \\
\text { and beneficially rather than aiming at making us achieve } \\
\text { high scores" } \\
\text { "I tend not to forget the vocabularies as opposed to other } \\
\text { classes" } \\
\text { "It is not just the usual way of memorizing vocabulary } \\
\text { and then forgetting them later" } \\
\text { "I wish other classes could adopt the same method as it } \\
\text { is better for education" } \\
\text { "They helped me to better remember and understand } \\
\text { vocabulary in comparison with the ordinary method of } \\
\text { studying them" }\end{array}$ & $\begin{array}{l}3 \\
\\
14 \\
16 \\
30 \\
31\end{array}$ \\
\hline
\end{tabular}




\begin{tabular}{|c|c|c|c|c|c|}
\hline 9 & Learning of English & 5 & $15 \%$ & & \\
\hline 9.1 & $\begin{array}{l}\text { Learning of English } \\
\text { (General } \\
\text { improvement) }\end{array}$ & 1 & $3 \%$ & "It has significantly improved my language" & 15 \\
\hline 9.2 & $\begin{array}{l}\text { learning of English } \\
\text { (Manner of } \\
\text { learning: easiness) }\end{array}$ & 2 & $4 \%$ & $\begin{array}{l}\text { "It made the English course a lot easier to me" } \\
\text { "Critical thinking strategies made learning English } \\
\text { language easier. Critical thinking strategies made } \\
\text { English language simple and not complicated and } \\
\text { restrained by rules. Critical thinking strategies made } \\
\text { learning English language based on understanding rather } \\
\text { than memorization" }\end{array}$ & $\begin{array}{l}8 \\
9\end{array}$ \\
\hline 9.3 & $\begin{array}{l}\text { learning of English } \\
\text { (Manner of } \\
\text { learning: speed) }\end{array}$ & 2 & $6 \%$ & $\begin{array}{l}\text { "Critical thinking strategies made learning English } \\
\text { language easier, faster and deeper" } \\
\text { "Learning was so rapid" }\end{array}$ & 9 \\
\hline 10 & Reflection & 1 & $3 \%$ & "It helped me in connecting them with my personal life" & 11 \\
\hline 11 & Empowerment & 1 & $3 \%$ & $\begin{array}{l}\text { "Such discussions could make the student more } \\
\text { confident in talking" }\end{array}$ & 25 \\
\hline
\end{tabular}

\section{Appendix C}

The Analysis of Students' Answers to the Second Open-ended Question

\section{Copyrights}

Copyright for this article is retained by the author(s), with first publication rights granted to the journal.

This is an open-access article distributed under the terms and conditions of the Creative Commons Attribution license (http://creativecommons.org/licenses/by/4.0/). 


\begin{tabular}{|c|c|c|c|c|c|}
\hline No. & Category & $\mathrm{n}$ & $\%$ & Students' Comments & St. \\
\hline 1 & $\begin{array}{l}\text { General Positive } \\
\text { Description }\end{array}$ & 28 & $82 \%$ & $\begin{array}{l}\text { "I have extremely benefitted" } \\
\text { "Thank Allah, it was beautiful" } \\
\text { "It was a delightfful experience" } \\
\text { "Beneficial and delightful" } \\
\text { "It was a significant and beautiful experience" } \\
\text { "It was absolutely delightful" } \\
\text { "It was a wonderful...experience.... That experience } \\
\text { made the relationship between critical thinking and } \\
\text { learning English language clearer for me" } \\
\text { "It was a distinctive experience" } \\
\text { "It was a beautiful...experience where we have leamt } \\
\text { useful things" } \\
\text { "It was a very significant experience" } \\
\text { "Very useful" } \\
\text { "Beautiful and evidently clear in lectures" } \\
\text { "Indescribably wonderful" } \\
\text { "It was a very wonderful experience. My teacher, please } \\
\text { go on with this method because it helps a lot" } \\
\text { "It was a very useful experience" } \\
\text { "It was a very wonderful and great experience. I wish to } \\
\text { have this experience again" } \\
\text { "It was a really excellent experience. It was worth trying" } \\
\text { "It was wonderful" } \\
\text { "I learned a lot in terms of thinking in the class... I } \\
\text { benefited a lot and I do want not to miss a class. I really } \\
\text { realized why it is important to attend that class and how } \\
\text { much one losses if she misses it" } \\
\text { "It was...(a) useful experience" } \\
\text { "It was a wonderful and unique experience" } \\
\text { "It was a wonderful, delightful and informative } \\
\text { "It wexience" } \\
\text { "It was a wonderful experience" } \\
\text { "It was a man enjoyable and useful experience" } \\
\text { "This method works very well in teaching English } \\
\text { language. In some schools, English is handled as a school } \\
\text { subject, however, it should be considered more than that; } \\
\text { a language. This is because the way of teaching } \\
\text { vocabulary and grammar. I really liked this method and I } \\
\text { think it has been extremely useful for students" }\end{array}$ & $\begin{array}{l}10 \\
11 \\
12 \\
13 \\
14 \\
15 \\
18 \\
\\
19 \\
20 \\
\\
21 \\
22 \\
23\end{array}$ \\
\hline 2 & $\begin{array}{l}\text { Vocabulary } \\
\text { Learning and } \\
\text { Retention }\end{array}$ & 7 & $21 \%$ & $\begin{array}{l}\text { "It is a delightful experience in which we acquired lots of } \\
\text { vocabulary items with no chance of forgetting them" } \\
\text { "We gained new skills in how to employ words in } \\
\text { sentences" } \\
\text { "It was a very significant experience which improved my }\end{array}$ & $\begin{array}{l}1 \\
10 \\
12\end{array}$ \\
\hline
\end{tabular}




\begin{tabular}{|c|c|c|c|c|c|}
\hline & & & & $\begin{array}{l}\text { knowledge level of vocabulary meanings and items, my } \\
\text { speed in studying them and my ability to retain them" } \\
\text { "I like the experience because I feel I can describe and } \\
\text { understand the vocabulary" } \\
\text { "The activities helped a lot in studying and memorizing } \\
\text { vocabulary" } \\
\text { "I feel I will never forget these vocabularies" } \\
\text { "All the vocabulary I gained this way cannot be erased } \\
\text { from my memory" }\end{array}$ & $\begin{array}{l}16 \\
19 \\
26 \\
31\end{array}$ \\
\hline 3 & $\begin{array}{l}\text { Motivation/ } \\
\text { Engagement }\end{array}$ & 12 & $35 \%$ & $\begin{array}{l}\text { "I have...immensely enjoyed this strategy. It also added a } \\
\text { lot of fun and joy to the class....Much obliged for this } \\
\text { experience and for the joy I felt in your class (addressing } \\
\text { the researcher)" } \\
\text { "I enjoyed the stories I authored and the delightful way in } \\
\text { which I acquired vocabulary items" } \\
\text { "It was also enjoyable and beneficial at the same time" } \\
\text { "It was... an enjoyable experience" } \\
\text { "Extremely enjoyable" } \\
\text { "I felt enthusiastic for the classes" } \\
\text { "It was a highly enjoyable experience... The class was no } \\
\text { more boring; it was not just reading and writing anymore" } \\
\text { "It was a very enjoyable...experience" } \\
\text { "It was an enjoyable and exciting experience" } \\
\text { "Classes were much enjoyable than usual" } \\
\text { "It was ... (a) useful experience" } \\
\text { "It was an interesting and exciting experience" }\end{array}$ & $\begin{array}{l} \\
3 \\
10 \\
11 \\
15 \\
22 \\
23 \\
24 \\
26 \\
30 \\
33 \\
34\end{array}$ \\
\hline 4 & $\begin{array}{l}\text { Preference over } \\
\text { other vocabulary } \\
\text { instruction methods }\end{array}$ & 6 & $18 \%$ & $\begin{array}{l}\text { "I wish I have been able to take a whole course with you } \\
\text { (addressing the researcher)" } \\
\text { "I wish that had been longer than that" } \\
\text { "I wish if we have used this method with all the words } \\
\text { that we have learned in the curriculum" } \\
\text { "Each day I would hope that Ms. Budor (the researcher) } \\
\text { would take our class. I wish she had employed the } \\
\text { strategies with us unil the last unit" } \\
\text { "I wish it could be applied every year to make it easier for } \\
\text { students to learn" } \\
\text { "I suggest it should be adopted everywhere" }\end{array}$ & $\begin{array}{l}2 \\
5 \\
17 \\
29 \\
32 \\
33\end{array}$ \\
\hline 5 & $\begin{array}{l}\text { Student-centered } \\
\text { Learning }\end{array}$ & 1 & $3 \%$ & $\begin{array}{l}\text { "Our teacher helped us interact and actively participate in } \\
\text { class" }\end{array}$ & 1 \\
\hline
\end{tabular}

\section{Copyrights}

Copyright for this article is retained by the author(s), with first publication rights granted to the journal.

This is an open-access article distributed under the terms and conditions of the Creative Commons Attribution license (http://creativecommons.org/licenses/by/4.0/). 